\title{
Morpho-anatomical characterization of diaspores and seedlings of Livistona rotundifolia ${ }^{(1)}$
}

\author{
FÁBIO ALESSANDRO PADILHA VIANA ${ }^{(2)}$, ANNE PINHEIRO COSTA ${ }^{(2) *}$,FABÍOLA VITTI MORO ${ }^{(3)}$ \\ and KATHIA FERNANDES LOPES PIVETTA ${ }^{(4)}$
}

\begin{abstract}
Livistona rotundifolia (Lam.) Mart. (Arecaceae) is an ornamentally important species used for landscaping and commonly grown as a potted plant. However, seedling production is hindered by the lack of information available about the species germination process and it could be subsidized by seed and seedling anatomical and morphological studies. Therefore, this study aimed at describing L. rotundifolia diaspore morphology in addition to seedling morphology and anatomy. Germination is tubular remote and begins with the opening of a circular operculum in the fruit endocarp through which the cotyledonary petiole is emitted. The endosperm is consumed as cotyledonary petiole grows. Eophyll is covered by two leaf sheaths and the first L. rotundifolia leaves are simple and lanceolate, with longitudinal and parallel veins. The developing cotyledonary petiole presents root hairs and a typical stem structure. The cotyledonary petiole/root transition region shows secondary root emission, parenchyma cells, and groups of fiber bundles. Roots present a well-defined cortex with polyarc vascular cylinder. Cortex and vascular cylinder are not well-differentiated in the root apex. The results of this study will contribute to the overall biology of L. rotundifolia, as well as to seedling production and species identification, subsidizing regeneration and conservation studies.
\end{abstract}

Keywords: Arecaceae, landscaping, ornamental, seeds.

\section{RESUMO}

Caracterização morfo-anatômica de diásporos e plântulas de Livistona rotundifolia

Livistona rotundifolia (Lam.) Mart. (Arecaceae) é uma importante espécie ornamental utilizada em paisagismo e comumente cultivada em vasos. Entretanto, a produção de plântulas é dificultada pela escassez de informações disponíveis acerca do processo de germinação da espécie, e poderia ser subsidiada por estudos anatômicos e morfológicos da semente e da plântula. Portanto, este estudo objetivou descrever a morfologia do diásporo de L. rotundifolia além da morfologia e anatomia da plântula. A germinação é remota tubular e se inicia com a abertura de um opérculo circular no endocarpo do fruto, por onde emerge o pecíolo cotiledonar. $\mathrm{O}$ endosperma é consumido à medida que o pecíolo cotiledonar cresce. O eófilo é coberto por duas bainhas e as primeiras folhas de $L$. rotundifolia são simples e lanceoladas, com venação longitudinal e paralela. O pecíolo cotiledonar em desenvolvimento apresenta pelos absorventes e estrutura típica de caule. A região de transição pecíolo cotiledonar/raiz apresenta emissão de raiz secundária, células parenquimáticas e diversos grupos de feixes de fibras. A raiz apresenta córtex bem definido com cilindro vascular poliarco. Córtex e cilindro vascular são pouco diferenciados no ápice da raiz. Os resultados deste estudo irão contribuir para a biologia geral de L. rotundifolia, bem como para a produção de mudas e identificação da espécie, subsidiando estudos de regeneração e conservação.

Palavras-chave: Arecaceae, paisagismo, ornamental, sementes.

\section{INTRODUCTION}

Palm trees belong to the Arecaceae family and are among the oldest trees in the planet (DRANSFIELD et al., 2008). Over 3500 species of palm trees have been described and they are distributed in tropical and subtropical regions (LORENZI et al., 1996). In Brazil, palm trees present great potential as food source, for biodiesel production, in the cosmetics industry, and as ornamental plants (CLEMENT et al., 2005).

Livistona R.Br. is one of the most ecologically diverse and widespread genera of palms, exhibiting horticultural, economic, and ecological importance. L. rotundifolia (Lam.) Mart., also known as footstool or queen palm, is a highly variable species native to Malaysia, Indonesia, and Philipines, but it is cultivated all over the world in tropical and subtropical countries (DOWE, 2009). It is an ornamentally important species used for landscaping and commonly grown as a tolerant indoor pot plant (SVINNINGEN et al., 2010).

This species has a single stem with prominent and dark leaf scar rings. Its stem may reach up to $45 \mathrm{~m}$ tall and $15-25 \mathrm{~cm}$ diameter. Leaves are large and form a globose crown. They are regularly segmented, with a bifurcate cleft on the leaf terminal portion. The inflorescence is a panicle of small yellowish flowers followed by clusters of yellow fruits, ripening to orange-red to red or to dark violet or black (DOWE, 2009). Seeds are recalcitrant, exhibit a

\footnotetext{
(1) Received in 03/08/2016 and accepted in 06/10/2016

(2) Universidade de Brasília (UnB), Faculdade de Agronomia e Medicina Veterinária, Brasília-DF, Brazil. *Corresponding author: annecosta@gmail.com

(3) Universidade Estadual Paulista Júlio de Mesquita Filho (UNESP), Departamento de Biologia Aplicada à Agropecuária, Jaboticabal-SP, Brazil.

(4) Universidade Estadual Paulista Júlio de Mesquita Filho (UNESP), Departamento de Produção Vegetal, Jaboticabal-SP, Brazil.
} 
low embryo: seed ratio, require darkness for germination, and show a slight non-deep physiological dormancy (SANJEEWANI et al., 2013). As stated by Viana et al. (2013), pulp removal increases germination rate whereas seed storage decreases the percentage of germinated seeds.

The Arecaceae family displays a peculiar development of the basic structures related to germination process. In addition, distinct seedling development patterns have been described among the different species of this family (HENDERSON, 2006). Thus, studies examining the structural aspects involved in germination and seedling development are of great importance as these plants, with a few exceptions, are only propagated by seeds, besides presenting a slow and non-uniform germination (HENDERSON, 2006; MEEROW and BROSCHAT, 2015). However, germination process has not been completely described neither has seedling structures been identified for most palm trees (GENTIL and FERREIRA, 2005). Morpho-anatomical studies could provide useful information for germination tests interpretation (OLIVEIRA and PEREIRA, 1986) and for taxonomic, ecologic, and agronomic studies (FERREIRA et al., 2001; GENTIL and FERREIRA, 2005), assisting in the production of high quality seedlings and natural regeneration studies (BOTELHO et al., 2000; MELO and VARELA, 2006).

In spite of the importance of $L$. rotundifolia as an ornamental plant, studies characterizing palm trees seed and seedling morphology and anatomy have only been restricted to a few species (DEMASON, 1988; AGUIAR and MENDONÇA, 2002; IOSSI et al., 2006; LUIS et al., 2010; MOURA et al., 2010; RIBEIRO et al., 2012; NEVES et al., 2013), hindering $L$. rotundifolia seedling production and, as a consequence, its extensive use. The lack of published data on seed and seedling initial development of this species directed the present study to investigate the basic diaspore morphology as well as seedling morphology and anatomy.

\section{MATERIAL AND METHODS}

L. rotundifolia diaspores were collected from a single mother plant at the School of Agrarian and Veterinarian Sciences (FCAV/ Unesp), situated in Jaboticabal, SP, Brazil. Diaspore diameter was given as a mean of 100 diaspores. Number of diaspores per kilogram and 1000-diaspore weight were calculated according to the Rules for Seed Testing [Regras para Análise de Sementes] (BRASIL, 2009).

A total of one hundred diaspores were used for morphological and anatomical studies. Diaspores were immersed in water for $24 \mathrm{~h}$, pulped, and then sown in unperforated plastic trays $(50 \times 25 \times 0.6 \mathrm{~cm})$ with moistened sphagnum moss for germination. They were half-buried in the substratum with the micropyle region faced down. Trays were kept under room temperature $\left(25.6\right.$ to $\left.32.8{ }^{\circ} \mathrm{C}\right)$ and were daily sprayed with water $(40$ $\mathrm{mL}$ ) in order to keep the moisture from the substratum surface.

For germination process description, representative samples of the different germination phases were taken, characterizing the seedling sequential development. Samples were FAA-fixed (formalin-acetic acid-alcohol) (JOHANSEN, 1940) for posterior analyses. Diaspore external and internal sides, embryo, and seedling developmental stages were outlined under bright-field microscope (Jenaval Universal, Carl Zeiss, Germany) according to Tomlinson (1961).

After germination initiation, representative samples of each developmental stage were selected for anatomical evaluations. Samples were taken from the mid and terminal region of the cotyledonary petiole (embryophore), shoot, cotyledonary petiole/shoot insertion region, swollen region above primary root, primary root mid region, and primary root apex. Samples were FAA-fixed for ten days and then dehydrated by graded ethanol and tert-butyl alcohol series (JOHANSEN, 1940). They were paraffin-embedded and sectioned in a microtone (Leica RM 2065, Germany). Afterwards, sections were deparaffinized, rehydrated, safranin stained, and dehydrated according to Johansen (1940). Once dehydrated, sections were mounted between slide and cover slip with Canadian balsam and let dry for fifteen days prior observation under a Docuval microscope (Carl Zeiss, Germany) and photographic register (Kodak PX-Pan, ISO 400 Film).

\section{RESULTS AND DISCUSSION}

L. rotundifolia diaspores are globous and present an average diameter of $12.14 \mathrm{~mm}$ (Figure 1A), as also reported by Dowe (2009). It was verified that 1000 diaspores weight $1,085.9 \mathrm{~g}$ and $1 \mathrm{~kg}$ contains 921 diaspores. Seeds are albuminous and the rigid endosperm almost fully occupies the diaspore inner space (Figures 1B-C). As stated by Dowe (2009), L. rotundifolia endosperm intrudes for twothirds to almost full width of the seed. Seed rigidness has also been observed in Archontophoenix alexandrae and $A$. cunninghamii diaspores (CHARLO et al., 2006; LUZ et al., 2012) and could be related to high fiber amounts in the seed (VALLILO et al., 2004). The embryo has characteristics of other palm species, since it is peripheral, lateral, conical, and poorly differentiated (Figure 1D) (CHARLO et al., 2006; BATISTA et al., 2011). 


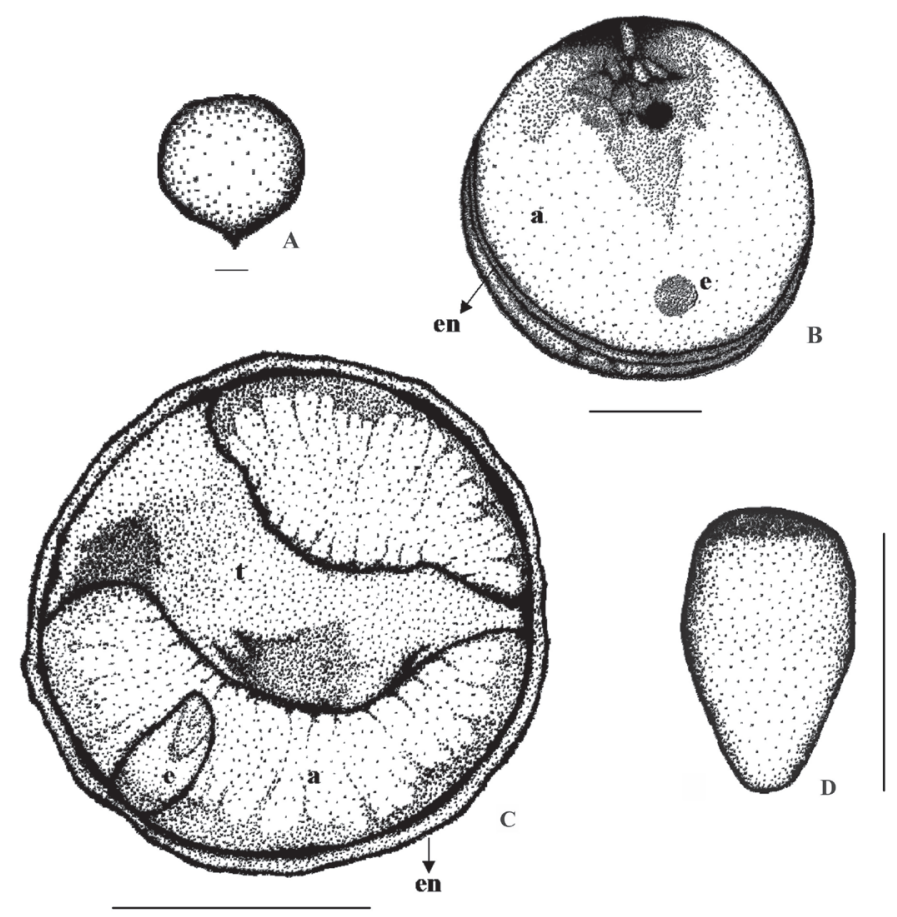

Figure 1. Diaspore morphology of Livistona rotundifolia. A) Diaspore in frontal view. B) Diaspore in frontal view showing endosperm and embryo after partial removal of endocarp. C) Diaspore in longitudinal section, showing the embryo, endosperm, and seed tegument invagination. D) Embryo. a, albumen or endosperm; e, embryo; en, endocarp; $t$, seed tegument invagination. Scale bars: $3 \mathrm{~mm}$.

L. rotundifolia seeds demonstrate a morphological germinative pattern classified as tubular remote. There is a pronounced elongation of the cotyledonary petiole containing the embryonic axis. The cotyledonary axis grows downward into the soil and swells at its base. Radicle and plumule emerge from this swelling. No ligule is formed (UHL and DRANSFIELD, 1987; MEEROW and BROSCHAT, 2015). Germination occurs between 15 and 40 days. It begins with the opening of a circular operculum in the fruit endocarp (Figure 2A), through which a bulbous and hollow structure (cotyledonary petiole or embryophore) is emitted (Figure 2B). According to Meerow and Broschat (2015), the cotyledonary petiole is an elongation of the actual cotyledon. The cotyledon or seed leaf remains inside the seed and functions as an absorptive organ called the haustorium. This haustorium is typical of Arecaceae embryos and contributes for the hydrolyses of lipid, protein, and carbohydrate reserves, as well as for nutrient mobilization from the endosperm to the emerging seedling (VERDEIL and HOCHER, 2002). Hence, as cotyledonary petiole grows (Figure $2 \mathrm{C})$, haustorium develops and the endosperm is gradually consumed (Figure 2D). Similar germination process was reported for other species from Arecaceae family, such as Phoenix roebelinii (IOSSI et al., 2006) and Syagrus oleracea (BATISTA et al., 2011). 


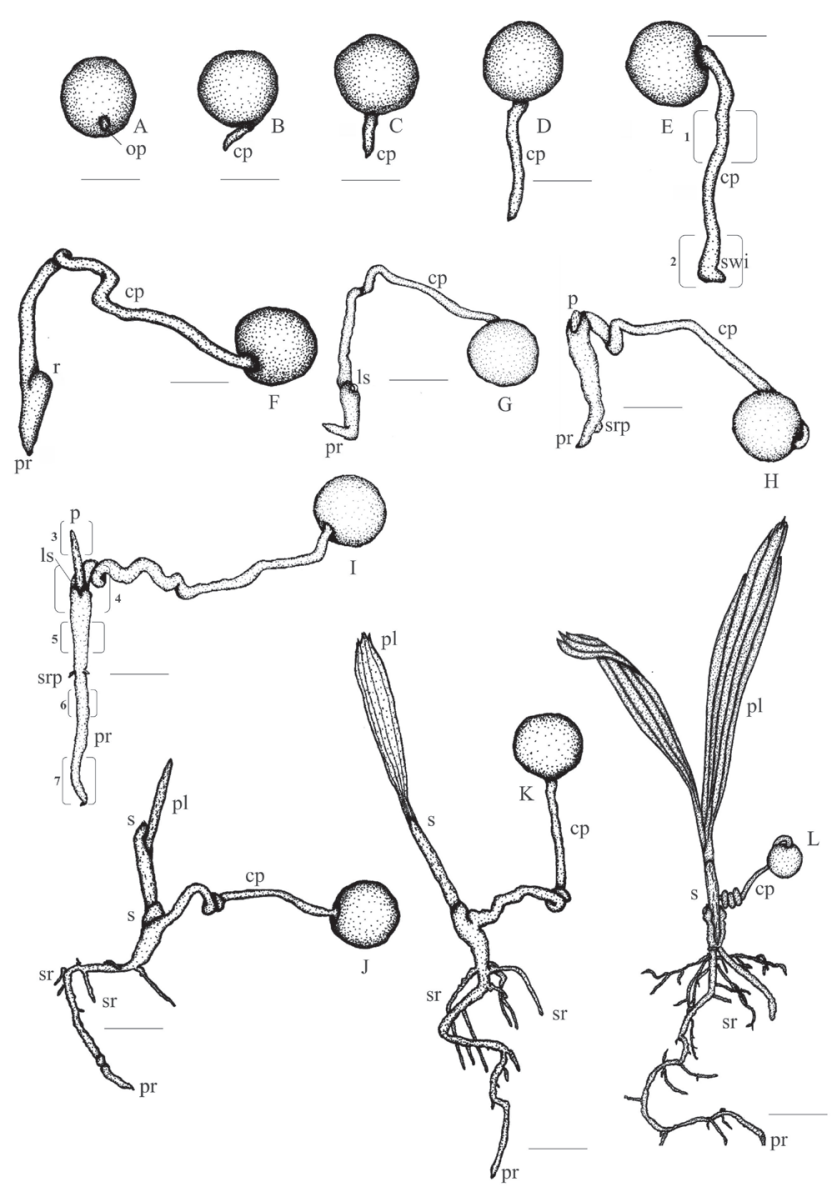

Figure 2. External morphology of diaspore germination and seedling development in Livistona rotundifolia. A) Circular operculum through which the cotyledonary petiole is emitted. B-D) Cotyledonary petiole progressive growth stages. E) Swelling initiation from cotyledonary petiole extremity. Numbers 1 (cotyledonary petiole mid region) and 2 (cotyledonary petiole terminal region) indicate the areas where samples were taken for anatomical studies. F) Longitudinal slit and primary root differentiation. G) Longitudinal slit opening. H) Plumule emergence initiation and secondary root growth initiation. I) Primary root growth and plumule emergence. Numbers 3 (shoot), 4 (cotyledonary petiole/shoot insertion region), 5 (swollen region above primary root), 6 (primary root mid region), and 7 (primary root apex) indicate the areas where samples were taken for anatomical studies. J) Primary and secondary root growth, sheath opening, and primary leaf (primary eophyll) emergence. K-L) Primary and secondary root and primary leaf growth. $\mathrm{cp}$, cotyledonary petiole; ls, longitudinal slit; op, circular operculum; pr, primary root; $p$, plumule; pl, primary leaf or primary eophyll; r, longitudinal slit differentiation region; s, sheath; sr, secondary root; srp, secondary root primordia; swi, swelling initiation. Scale bars: $10 \mathrm{~mm}$.

When the cotyledonary petiole reaches approximately $10 \mathrm{~cm}$, a swollen region is detected at its extremity (Figure 2E). A longitudinal slit differentiation area and primary root differentiation can be observed at the end of this swollen region (Figure 2F). Subsequently, main root growth and a longitudinal slit opening (Figure $2 \mathrm{G}$ ) - from where plumule emerges (Figures 2H-I) - are distinguished. Two leaf primordia (sheaths) cover the first complete juvenile leaf (eophyll) (Figure 2J) and secondary roots are observed in this phase (Figure $2 \mathrm{~K}$ ). The first L. rotundifolia leaves are simple and lanceolate, with longitudinal and parallel veins (Figure 2L).
The cotyledonary petiole tip exhibits root hair and present a typical stem structure (Figure 3A). Epidermal cells are small and compact, with no intercellular spaces. Hypoderm presents several layers of small and thick-walled cells. Parenchyma cells are the predominant cells in cortex in which scattered vascular tissues are found. The arrangement of vascular tissues within the bundle is collateral and vascular bundles are arranged in a ring. The central core of the cotyledonary petiole is also composed of parenchyma cells. The cotyledonary petiole mid portion demonstrates similar structure to its end section (Figure 3B). However, there is no root hair in the mid portion. 


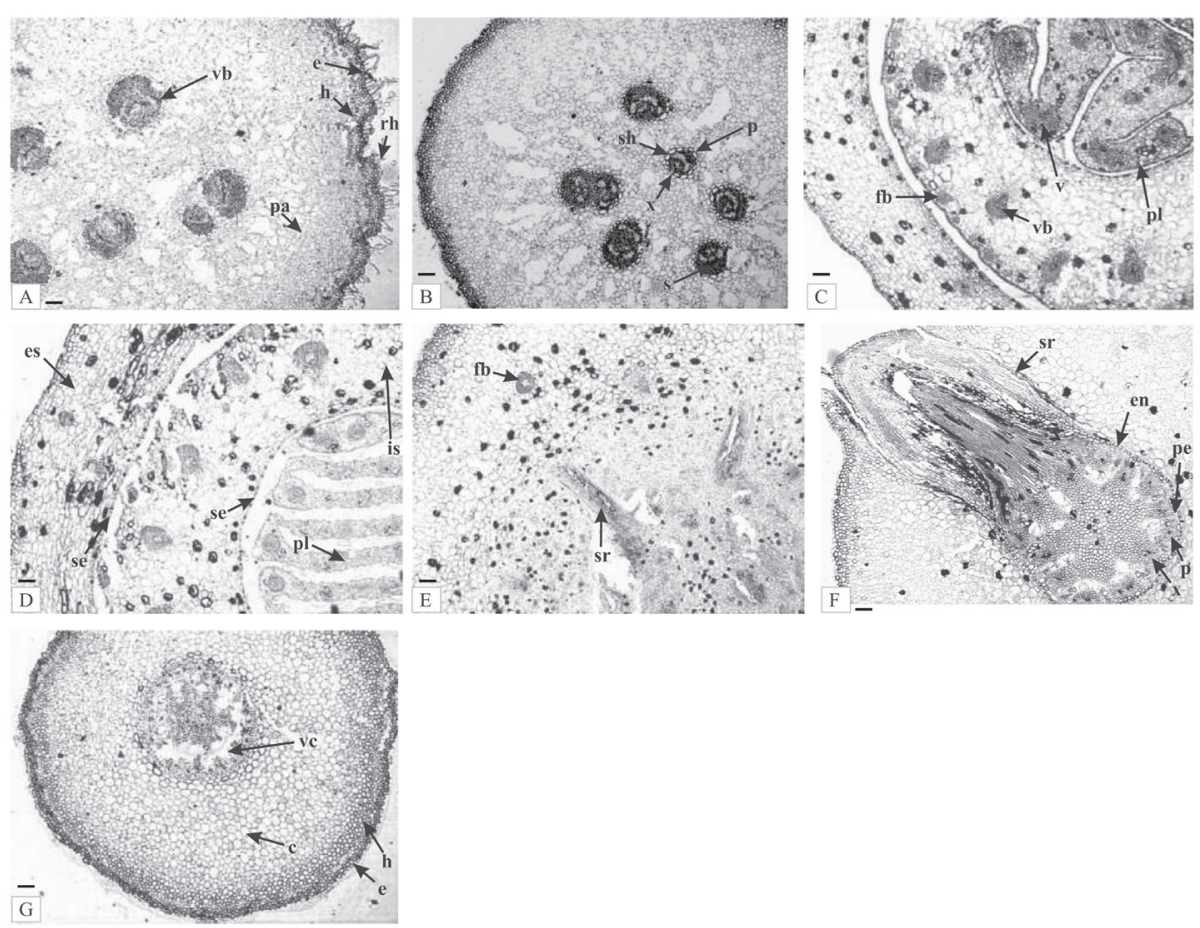

Figure 3. Anatomical transversal sections of Livistona rotundifolia seedlings. A) Cotyledonary petiole apex. Scale bar: $40 \mu \mathrm{m}$. B) Cotyledonary petiole mid region. Scale bar: $40 \mu \mathrm{m}$. C) Seedling shoot. Scale bar: $40 \mu \mathrm{m}$. D) Shoot/ root transition region. Scale bar: $40 \mu \mathrm{m}$. E) Cotyledonary petiole/root transition region. Scale bar: $40 \mu \mathrm{m}$. F) Seedling root showing secondary root growth. Scale bar: $20 \mu \mathrm{m} . \mathrm{G})$ Root apex. Scale bar: $50 \mu \mathrm{m}$. c, cortex; e, epidermis; en, endodermis; es, external sheath; is, internal sheath; fb, fiber bundle; h, hypodermis; $p$, phloem; pa, parenchyma; pe, pericycle; pl, primary leaf or eophyll; rh, root hair; s, sclerenchyma cells; se, sheath epidermis; sh, sheath; sr, secondary root; v, vein; vb, vascular bundle; vc, vascular cylinder; $\mathrm{x}$, xylem.

Transverse sections from seedling shoots revealed that primary leaves are covered by two leaf sheaths and occupy its central core (Figure 3C). Leaf sheaths present a wider portion which gradually decreases in thickness. A single-cell layer is observed in the internal as well as in the external epidermis of the leaf sheaths whereas mesophyll is composed of parenchyma cells. The inner sheath shows equally spaced vascular bundles, forming an inner and an outer circle. Vascular bundles present sclerenchyma cells and consist of the xylem vessels on the inside and the phloem on the outside. The outer sheath is non-vascularized and the primary leaf is found folded upon itself on the inside of the sheath. This leaf is quite plicated and already shows its parallel vein distribution. Both primary leaf surfaces exhibit a single cell layer and the homogeneous mesophyll is constituted by polyedric parenchyma cells with similar diameters. Vascular bundles of different callipers are found in the leaf and those with greatest callipers are observed closer to the abaxial leaf surface.

Shoot/root transition region is similar to shoot regarding its structure (Figure 3D). However, a greater number of folds are found in the eophyll of the shoot/root transition region, indicating a wider leaf base.

Secondary root emission is observed in the transition region between cotyledonary petiole and root. These roots are formed inside the vascular cylinder and then head towards its periphery (Figure 3E). Different cell layers comprised of small and tick-walled cells are developed by the epidermis corresponding region. Parenchyma cells and several groups of fiber bundles make up the cortex. The vascular cylinder is polyarc and occupies the secondary root central portion. Vascular tissues are characterized by the typical anatomy of an exarch xylem and an alternated arrangement of xylem and phloem (Figure 3F). A well-defined endoderm and a double-layer pericycle are observed. The cortex is composed of parenchyma cells which increase in size towards root periphery.

In the primary root apex, hypodermis is welldifferentiated and the vascular cylinder remains in the central portion of the root. Epidermis presents two to three layers of small and thick-walled cells (Figure 3G). Cortex and vascular cylinder are not well-differentiated.

\section{CONCLUSIONS}

Seed and seedling morpho-anatomical studies in palm trees are scarce considering the family importance, diversity, and complexity. To date, very little is known about $L$. rotundifolia seed and seedling morphology and anatomy. Therefore, this study will contribute to our understanding of $L$. rotundifolia biological cycle, as well as for its seedling production and species identification, subsidizing regeneration and conservation studies. 


\section{REFERENCES}

AGUIAR, M.O.; MENDONÇA, M.S. Aspectos morfoanatômicos do embrião de Euterpe precatoria Mart. durante o processo germinativo. Acta Botanica Brasilica, v.16, n.3, p.241-249, 2002. DOI: <10.1590/S0102$33062002000300001>$

BATISTA, G.S.; COSTA, R.S.; GIMENES, R.; PIVETTA, K.F.L.; MÔRO, F.V. Aspectos morfológicos dos diásporos e das plântulas de Syagrus oleracea (Mart.) Becc-Arecaceae. Comunicata Scientiae, v.2, n.3, p.170-176, 2011.

BOTELHO, A.S.; FERREIRA, R.A.; MALAVASI, M.M.; DAVIDE, A.C. Aspectos morfológicos de frutos, sementes, plântulas e mudas de Jatobá-do-cerrado (Hymenaea stigonocarpa Mart. ex Hayne) - Fabaceae. Revista Brasileira de Sementes, v.22, n.1, p.144-152, 2000.

BRASIL. Ministério da Agricultura, Pecuária e Abastecimento. Regras para análise de sementes. Brasília: MAPA/ACS, 2009. 398p.

CHARLO, H.C.O.; MÔRO, F.V.; SILVA, V.S.; SILVA, B.M.S.; BIANCO, S.; MÔRO, J.R. Aspectos morfológicos, germinação e desenvolvimento inicial de plântulas de Archontophoenix alexandrae (F. Mueller) H. Wendl. e Drude (Arecaceae) em diferentes substratos. Revista Árvore, v.30, n.6, p.933-940, 2006. DOI: <10.1590/S010067622006000600008>

CLEMENT, C.R.; LLERAS, E.; VAN LEEWEN, J. O potencial das palmeiras tropicais no Brasil: acertos e fracassos das últimas décadas. Agrociência, v.9, n.1-2, p.67-71, 2005.

DEMASON, D.A. Embryo structure and storage reserve histochemistry in the palm Washingtonia filifera. American Journal of Botany, v.75, p.330-337, 1988.

DOWE, J.L. A taxonomic account for Livistona R.Br. (Arecaceae). Garden's Bulletin Singapore, v.60, n.2, p.11-175, 2009.

DRANSFIELD, J.; UHL, N.W.; ASMUSSEN, C.B.; BAKER, W.J.; HARLEY, M.M.; LEWIS, C.E. Genera Palmarum: the evolution and classification of palms. Londres: Kew Publishing, 2008. 732p.

FERREIRA, R.A.; VIEIRA, M.G.G.C.; VON PINHO, E.U.R.; TONETTI, O.A.O. Morfologia de sementes e de plântulas e avaliação da viabilidade da semente de sucupira branca (Pterodon pubescens Benth - Fabaceae) pelo teste de tetrazólio. Revista Brasileira de Sementes, v.23, n.1, p.108-115, 2001. DOI: <10.17801/0101-3122/rbs. v23n1p108-115>
GENTIL, D.F.O;; FERREIRA, S.A.N. Morfologia da plântula em desenvolvimento de Astrocaryum aculeatum Meyer (Arecaceae). Acta Amazônica, v.35, n.3, p.337342, 2005. DOI: <10.1590/S0044-59672005000300005>

HENDERSON, F.M. Morphology and anatomy of palm seedlings. Botanical Review, v.72, n.4, p.273-329, 2006. DOI: $\quad<10.1663 / 0006-8101(2006) 72[273: M A A O P S] 2.0$. $\mathrm{CO} ; 2>$

IOSSI, E.; MORO, F.V.; SADER, R. Seed anatomy and germination of Phoenix roebelenii O'Brien (Arecaceae). Revista Brasileira de Sementes, v.28, n.3, p.121-128, 2006. DOI: <10.1590/S0101-31222006000300018>

JOHANSEN, D.A. Plant microtechnique. 1st. ed. New York: McGraw-Hill Book Company, 1940. 523p.

LORENZI, H.; SOUZA, H.M.; MEDEIROS-COSTA, J.T.; CERQUEIRA, L.S.C.; VON BEHR, N. Palmeiras no Brasil: nativas e exóticas. Nova Odessa: Plantarum, 1996. 241p.

LUIS, Z.G.; BEZERRA, K.M.G.; SCHERWINSKIPEREIRA, J.E. Adaptability and leaf anatomical features in oil palm seedlings produced by embryo rescue and pregerminated seeds. Brazilian Journal of Plant Physiology, v.22, n.3, p.209-215, 2010. DOI: <10.1590/S167704202010000300008>

LUZ, P.B.; PIVETTA, K.F.L.; NEVES, L.G.; SOBRINHO, S.P.; BARELLI, M.A.A. Caracterização morfológica do diásporo e da plântula de Archontophoenix cunninghamii (Arecaceae). Comunicata Scientiae, v.3, n.4, p.244-248, 2012.

MEEROW, A.W; BROSCHAT, T. K. Palm seed germination. Fort Lauderdale: Cooperative Extension Service, 2015. 9p. (Bulletin, 274).

MELO, M.F.F.; VARELA, V.P. Aspectos morfológicos de frutos, sementes, germinação e plântulas de duas espécies florestais da Amazônia Dinizia excelsa Ducke (Angelim Pedra) e Cedrelinga catenaeformis Ducke (Cedrorana) Leguminosae: Mimosoideae. Revista Brasileira de Sementes, v.28, n.1, p.54-62, 2006. DOI: $<10.1590 /$ S010131222006000100008>

MOURA, E.F.; VENTRELLA, M.C.; MOTOIKE, S.Y. Anatomy, histochemistry and ultrastructure of seed and somatic embryo of Acrocomia aculeata (Arecaceae). Scientia Agricola, v.67, n.4, p.399-407, 2010. DOI: <10.1590/ S0103-90162010000400004>

NEVES, S.C.; RIBEIRO, L.M.; CUNHA, I.R.G.; PIMENTA, M.A.S.; MERCADANTE-SIMÕES, M.O.; LOPES, P.S.N. Diaspore structure and germination ecophysiology of the babassu palm (Attalea vitrivir). Flora - Morphology, distribuition, functional ecology of plants, v.208, n.1, p.68-78, 2013. DOI: <10.1016/j.flora.2012.12.007> 
OLIVEIRA, A.E.C.; PEREIRA, T.S. Euphorbiaceae - morfologia da germinação de algumas espécies. Revista Brasileira de Sementes, v.9, n.1, p.9-29, 1986.

RIBEIRO, L.M.; OLIVEIRA, D.M.T.; GARCIA, Q.S. Structural evaluations of zygotic embryos and seedlings of the macaw palm (Acrocomia aculeata, Arecaceae) during in vitro germination. Trees, v.26, p.851-863, 2012. DOI: $<10.1007 / \mathrm{s} 00468-011-0659-2>$

SANJEEWANI, B.L.G.; JAYASURIYA, K.M.G.G.; FERNANDO, M.T.R.; DAMUNUPOLA, J.W. Storage and germination treatments for seeds of an ornamentally important palm, Livistona rotundifolia (Lam.) Mart. Journal of the National Science Foundation of Sri Lanka, v.41, n.4, p.273-277, 2013. DOI: <10.4038/jnsfsr. v41i4.6257>

SVINNINGEN, A.E.; JEGATHAMBIGAI, V.; MIKUNTHAN, G. Nomuraea rileyi: a plausible fungi selectively controlling lepidopteron, Paraponyx stratiotata L. damaging queen palm (Livistona rotundifolia L.). Communications in Agricultural Applied Biological Sciences, v.75, n.3, p.279-293, 2010.
TOMLINSON, P.B. Anatomy of the monocotyledons. In: TOMLINSON, P.B. Palmae. Oxford: Oxford University Press, 1961. p.308-311. vol. 2.

UHL, N.W.; DRANSFIELD, J. Genera Palmarum: a classification of palms based on the work of Harold $\mathbf{E}$. Moore Junior. 1st. ed. Lawrence: Allen Press, 1987. 610p.

VALLILO, M.I.; CRESTANA, C.S.M.; AUEDPIMENTEL, S.; TAVARES, M.; KUMAGAI, E.E.; GARBELOTTI, M.L. Composição química das sementes de Archontophoenix alexandrae H. Wendl. e Drude (Arecaceae). Revista Árvore, v.28, n.5, p.676-679, 2004. DOI: <10.1590/S0100-67622004000500006>

VERDEIL, J.L.; HOCHER, V. Digestion and absorption of food in plants: a plant stomach. Trends in Plant Science, v.7, p.280-281, 2002. DOI: <10.1016/S13601385(02)02269-0>

VIANA, F.A.P.; MÔRO, F.V.; BATISTA, G.S.; ROMANI, G.N.; MAZZINI, R.B.; PIVETTA, K.F.L. Maturity, pulp removal and storage effects on the germination of Livistona rotundifolia seeds. Acta Horticulturae, v.1003, p.197201, 2013. DOI: <10.17660/ActaHortic.2013.1003.28> 